\title{
Role of dopamine receptors subtypes, D1-like and D2-like, within the nucleus accumbens subregions, core and shell, on memory consolidation in the one-trial inhibitory avoidance task
}

\author{
Francesca Managò, ${ }^{1,2}$ Claudio Castellano, ${ }^{1-3}$ Alberto Oliverio, ${ }^{1-3}$ Andrea Mele, ${ }^{1-3}$ \\ and Elvira De Leonibus ${ }^{1,2,4,5}$ \\ ${ }^{1}$ Dipartimento di Genetica e Biologia Molecolare "C. Darwin," Università degli Studi di Roma "La Sapienza," Rome 00185, Italy; \\ ${ }^{2}$ Centro di Ricerca in Neurobiologia-D. Bovet, Università degli Studi di Roma "La Sapienza," Rome 00185, Italy; ${ }^{3}$ Istituto di \\ Neuroscienze-CNR, CERC, Rome 00143, Italy; ${ }^{4}$ TIGEM (Telethon Institute of Genetics and Medicine), Naples 80131, Italy
}

\begin{abstract}
Recent evidence demonstrated that dopamine within the nucleus accumbens mediates consolidation of both associative and nonassociative memories. However, the specific contribution of the nucleus accumbens subregions, core and shell, and of D1 and D2 receptors subtypes has not been yet clarified. The aim of this study was, therefore, to directly compare the effect of D1 and D2 dopamine receptor blockade within the core and the shell subregions of the nucleus accumbens on memory consolidation. Using the one-trial inhibitory avoidance task in CD1 mice, we demonstrated that SCH 23390 (vehicle, 12.5, 25, $50 \mathrm{ng} /$ side) administration within the core, but not the shell, impaired step-through latency $24 \mathrm{~h}$ after the administration if injected immediately, but not 120 min post-training. Interestingly, sulpiride (vehicle, 25, $50 \mathrm{ng} /$ side) injection in both the core and the shell of the accumbens affected step-through latency $24 \mathrm{~h}$ later; also, in this case the impairment was time dependent. These data provide the most complete and direct demonstration to date that early consolidation of aversive memory requires D2 receptor activation in both nucleus accumbens subregions, and D1 activation selectively in the nucleus accumbens core.
\end{abstract}

Dopamine (DA) within the nucleus accumbens (Nac) was initially regarded as crucial in mediating motivational properties of rewards and drugs of abuse (Di Chiara and Bassareo 2007). Recently, however, increasing attention is being focused on the learning and memory functions of DA within the Nac (Ploeger et al. 1994; Setlow and McGaugh 1998; Di Ciano et al. 2001; Di Ciano and Everitt 2004; Mele et al. 2004; Dalley et al. 2005; Ferretti et al. 2005; Cheng and Feenstra 2006; Bossert et al. 2007; Cheer et al. 2007; Kuo et al. 2007).

Recent experimental evidence, by means of post-training Nac focal administrations, demonstrated that DA is necessary for memory consolidation in a variety of behavioral tasks, such as the hidden version of the water maze, the object-place association, and the one-trial inhibitory avoidance tasks (Setlow and McGaugh 1998; Di Ciano et al. 2001; Mele et al. 2004; Dalley et al. 2005; Ferretti et al. 2005; LaLumiere et al. 2005). It must be said, however, that DA can act on different DA receptor subtypes, D1and D2-like; D1- and D2-like receptors are thought to have opposite effects on different forms of neuronal plasticity, and consequently on learning and memory, due to their opposite action on the cyclic adenosine monophosphate (cAMP)-dependent protein kinase A pathway (Cepeda and Levine 1998; Missale et al. 1998; Floresco et al. 2001a). It should also be mentioned that the Nac can be further distinguished in two different subregions, namely, the core and shell (Zahm and Brog 1992) that are believed to functionally differ (Cools et al. 1995; Koshikawa et al. 1996a,b;

${ }^{5}$ Corresponding author.

E-mail elvira.deleonibus@uniroma1.it; fax 39-81-5790919.

Article is online at http://www.learnmem.org/cgi/doi/10.1101//m.1177509.
Jongen-Rêlo et al. 2003; Di Chiara et al. 2004; Cheng and Feenstra 2006; De Leonibus et al. 2006; Schmidt et al. 2006). This assumption is based on the connectivity of the two components of the accumbens. In particular, the shell, differently from the core, has reciprocal connections with the hypothalamus and the mesencephalon; thus, it might act to let internal physiological status-related information (hypothalamic) influence behavior directly, via the ventral pallidum, or the motivational status, via its feedback to the mesencephalon to influence other striatal DA terminal subregions (Zahm and Brog 1992). Therefore, the shell is thought to have essentially motivational functions, while the core that receives dense projections from the hippocampus and the amygdala is believed to have a more specific role in learning and memory processes (Zahm and Brog 1992; Di Ciano et al. 2001; Di Ciano and Everitt 2004; Di Chiara and Bassareo 2007; da Cunha et al. 2008). It should also be noted that the two components of the Nac have been reported to have a heterogeneous dopamine receptor distribution. In fact, although D1 receptors are ubiquitously distributed within Nac subregions, D2 receptors are denser in the core than in the shell (Lu et al. 1998).

Such findings suggest that memory consolidation might be affected in different ways by manipulation of the different DA receptor subtype within the two Nac subregions. However, there is very little experimental evidence in the literature testing this hypothesis, and the results are in some cases contradictory (Setlow and McGaugh 1998; Dalley et al. 2005; Hernandez et al. 2005). The aim of this study was, therefore, to directly compare the role of D1 and D2 receptor subtypes within the core and the shell subregions of the Nac on memory consolidation. For this purpose, 
we studied the effects of immediate, or 120-min post-training D1 (SCH 23390) and D2 (sulpiride) antagonists' injection within the Nac core and shell in mice, on aversive associative memory consolidation in the one-trial inhibitory avoidance task. We studied aversive memory because of its own clinical relevance in post-traumatic stress disorder (PTSD), a mental illness that is characterized by recurrent distressing memories of traumatic events. Interestingly, recent experimental evidence in humans demonstrated that alteration in the activity of the nucleus accumbens, together with the amygdala, the hippocampus, and the ventromedial prefrontal cortex, are strictly correlated to the development of PTSD (Liberzon et al. 1999, 2007; Pavic et al. 2003). Therefore, we think that the results of this study might help to elucidate possible neuropathophysiological mechanisms underlying this mental disorder.

\section{Results}

\section{Histological verifications}

Figure 1 shows a schematic representation of the injector placements for Experiments 1-7, indicating the most ventral point for each injector track in the different groups. Injector placements located in the core and shell of the nucleus accumbens are reported in Figure 1A (Experiments 1 and 2), Figure 1B (Experiment 3), Figure 1C (Experiments 4 and 5), and Figure 1D (Experiments 6 and 7). No major difference in injector localization distribution was evident among groups in each experiment or between the two experiments. Only those animals displaying a correct placement were included in the statistical analysis. In Figure 2 we reported pictures of representative injector positions for the core (left) and the shell (right) made on coronal sections stained with cresyl violet.

\section{Effects of immediate post-training injections of dopamine DI} receptors antagonist, $\mathrm{SCH} 23390$, into the nucleus accumbens core or shell on memory consolidation in the one-trial inhibitory avoidance task

Table 1 shows that there were no significant pre-existing differences between groups on the training latency for animals later injected into the core $\left(F_{(3,34)}=\right.$ 1.307; $P>0.05)$ or the shell $\left(F_{(3,29)}=\right.$ $1.420 ; P>0.05)$. Immediate post-training injections of different doses of $\mathrm{SCH}$ 23390 into the nucleus accumbens core (Experiment 1) dose dependently reduced step-through latency $24 \mathrm{~h}$ later $\left(F_{(3,34)}=3.654 ; P<0.05\right)$. Post-hoc test revealed that the reduction was significant after the injection of both highest doses (Fig. 3A). On the contrary, immediate post-training injections of different doses of SCH 23390 into the nucleus accumbens shell (Fig. 3B) did not affect step-through latency $24 \mathrm{~h}$ later $\left(F_{(3,29)}=0.536 ; P>0.05\right)$.

\section{Effects of 120-min post-training injections of dopamine D1 receptors antagonist, $\mathrm{SCH} 23390$, into the nucleus accumbens core on memory consolidation in the one-trial inhibitory avoidance task \\ In this experiment (3), we tested whether the effects of D1 receptor blockade within the core on memory consolidation were time dependent. Also, in this case there were no pre-existing (Table 1) $\left(F_{(1,12)}=0.179 ; P>0.05\right)$ differences between the two groups.}
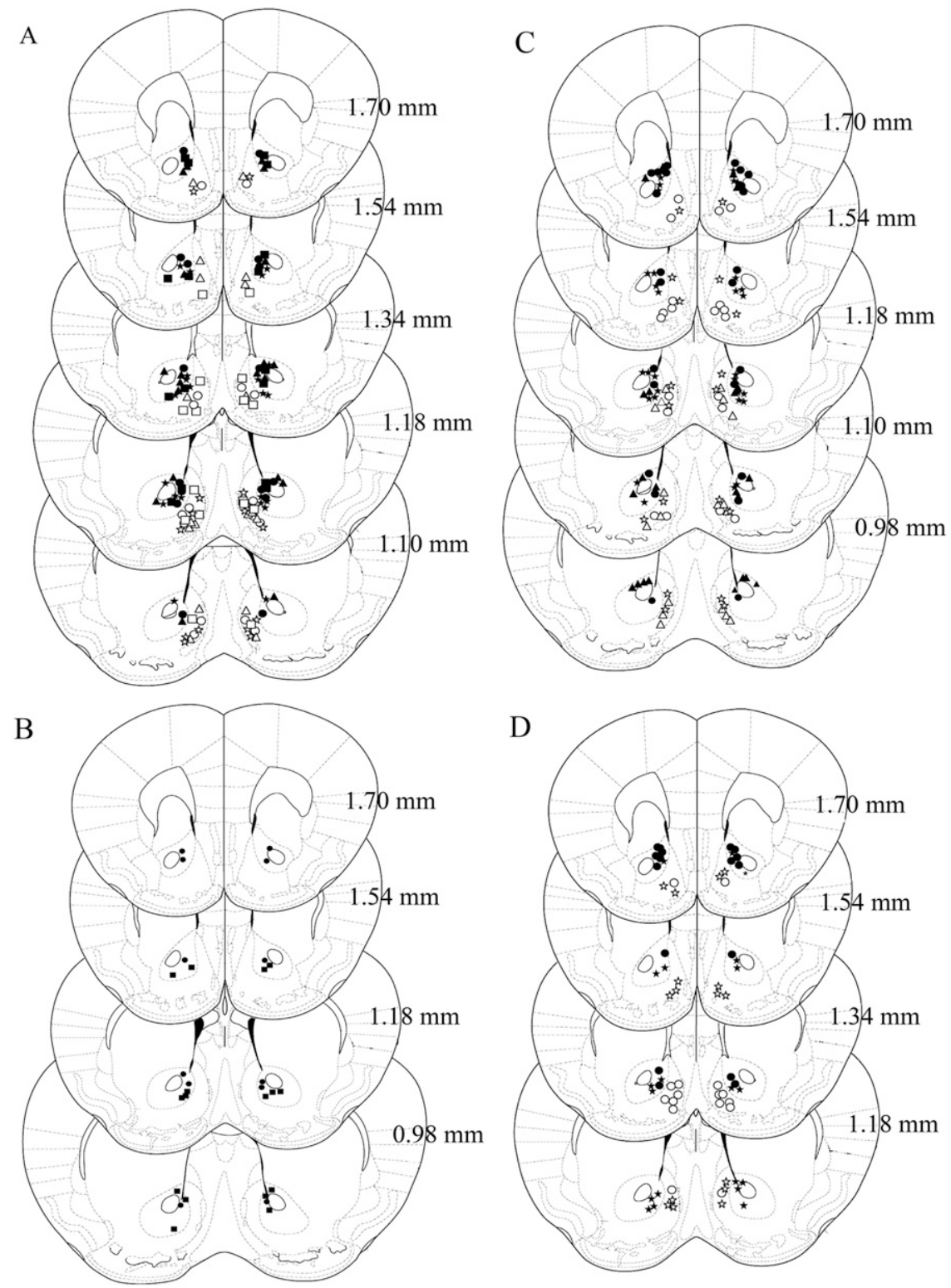

Figure 1. Sketches of coronal sections from animals in the seven experiments. Each symbol represents an injector placement. The numbers indicate the anteroposterior coordinate relative to bregma according to Franklin and Paxinos (1997). Open and filled symbols are used for the shell and core, respectively. $(A)$ Injector placements in Experiments 1 and 2; circle $=$ vehicle, triangle $=12.5 \mathrm{ng} /$ side, star = $25 \mathrm{ng} / \mathrm{side}$; square: dose $50 \mathrm{ng} / \mathrm{side}$ SCH 23390. (B) Injector placements in Experiment 3; circle = vehicle; square: dose $50 \mathrm{ng} /$ side of SCH 23390. (C) Injector placements in Experiments 4 and 5; circle $=$ vehicle, triangle $=12.5 \mathrm{ng} / \mathrm{side}$, star $=25 \mathrm{ng} / \mathrm{side}$ of sulpiride. $(D)$ Injector placements in Experiments 6 and 7; circle $=$ vehicle, star $=25 \mathrm{ng} /$ side of sulpiride. 


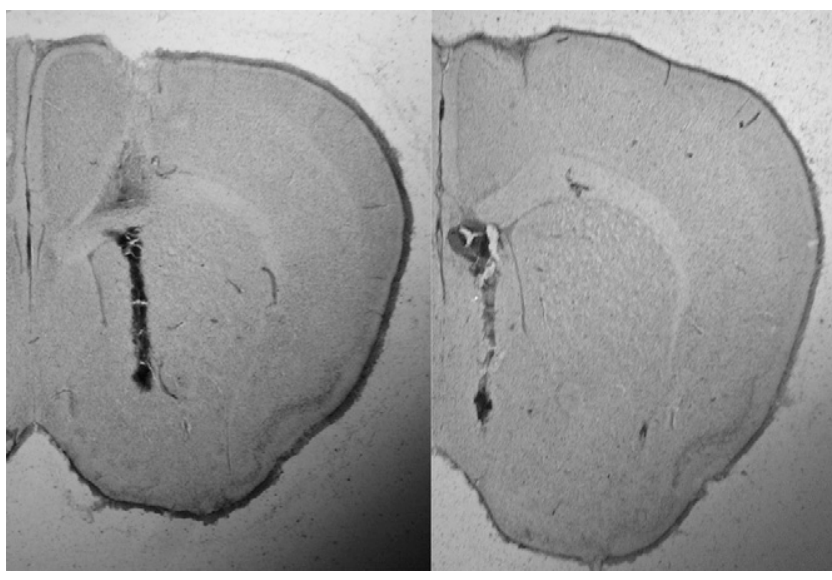

Figure 2. Representative picture of brain coronal section stained with cresyl violet for the core (left) and shell (right) of the Nac.

Furthermore, the highest dose of SCH 23390 (Fig. 4) that was fully effective if administered immediately post-training (Experiment 1 ) was completely ineffective when administered $120 \mathrm{~min}$ after training $\left(F_{(1,12)}=0.001 ; P>0.05\right)$.

\section{Effects of immediate post-training injections}

of dopamine D2 receptors antagonist, sulpiride, into the nucleus accumbens core or shell on memory consolidation in the one-trial inhibitory avoidance task

In this case also there were no significant pre-existing differences between groups (Table 1) on the training latency in the groups later injected in the core $\left(F_{(2,35)}=0.447 ; P>0.05\right)$ or in the shell $\left(F_{(2,25)}=0.941 ; P>0.05\right)$. Immediate post-training injections of different doses of sulpiride into the core dose dependently reduced step-through latency $24 \mathrm{~h}$ later $\left(F_{(2,29)}=6.332 ; P<0.05\right)$. The posthoc analysis revealed that the reduction was significant after the injection of the highest dose (Fig. 5A). Surprisingly, immediate post-training injections of different doses of sulpiride into the nucleus accumbens shell also significantly reduced step-through latency $24 \mathrm{~h}$ later $\left(F_{(2,25)}=4.772 ; P<0.05\right)$. The post-hoc test revealed that such an effect was significant for the highest dose (Fig. 5B) and almost approached statistical significance for the lowest dose $(P=0.067)$.

\section{Effects of 120-min post-training injections of dopamine D2 receptors antagonist, sulpiride, into the nucleus accumbens core or shell on memory consolidation in the one-trial inhibitory avoidance task}

In these two last experiments we tested whether the impairment in step-through latency observed in Experiments 5 and 6 was due to proactive effects of the drugs rather then to memory consolidation effects. In none of these experiments did we find, preexisting (Table1) [Experiment $6\left(F_{(1,174)}=0.257 ; P>0.05\right)$ and Experiment $\left.7\left(F_{(1,14)}=.381 ; P>0.05\right)\right]$ or post-injection [Experiment 5, Experiment $6\left(F_{(1,17)}=2.43 ; P>0.05\right)$ and Experiment 7 $\left.\left(F_{(1,14)}=4.2 ; P>0.05\right)\right]$, significant differences between groups, as shown in Figure 6, A and B.

\section{Discussion}

In this study we demonstrated that both subregions of the Nac, core and shell, and both dopamine receptors subtypes, D1 and D2, are involved in the consolidation of aversive associative memory. Furthermore, we dissociated for the first time in mice the specific contribution of the core and shell subregions in the same behavioral process. In particular, in the first two experiments we demonstrated that immediate post-training administrations of different doses of the D1 receptor antagonist dose dependently impaired step-through latency $24 \mathrm{~h}$ later when injected in the core, but not in the shell of the Nac. In the third experiment we proved that this effect was time dependent; in fact, when the highest dose of SCH 23390 was injected 120 min after training, no effects were observed $24 \mathrm{~h}$ later on the step-through latency. This clearly proved that the impairment induced by D1 receptors blockade within the core was not due to proactive effects of the drug, but was due to its specific action on memory consolidation. This first set of data confirmed that DA within the Nac mediates memory consolidation in the one-trial inhibitory avoidance task (LaLumiere et al. 2005). Furthermore, it was consistent with the general role attributed to the D1 receptor in long-term memory formation and in forms of neural plasticity mediated by its activation (Smith-Roe and Kelley 2000; Di Ciano et al. 2001; Floresco et al. 2001a; Wolf et al. 2003; Mele et al. 2004; Dalley et al. 2005; Ferretti et al. 2005; Navakkode et al. 2007; Surmeier et al. 2007). Finally, our results paralleled previous results obtained using an appetitive Pavlovian associative task, demonstrating a clear contribution of D1 receptor activation within the core subregion in memory consolidation (Dalley et al. 2005). We expanded this experimental evidence by demonstrating that aversive memory is independent of $\mathrm{D} 1$ receptor activation within the shell.

In the second set of experiments (Experiments 4-7) we tested the role of D2 receptors in aversive memory consolidation. The results of these experiments clearly demonstrated that immediate post-training D2 receptors blockade within the core or the shell impaired passive avoidance memory $24 \mathrm{~h}$ later. This effect was once again time dependent, since 120-min post-training administration was ineffective (Experiments 6 and 7). On the basis of our data, we cannot exclude that the generalized effect of sulpiride in the two regions was due to a spread of the drug from the core to the shell or vice versa. However, this hypothesis seems unlikely if we consider the low injection volume $(0.2 \mu \mathrm{L} /$ side $)$ used and the fact that the same volume of SCH 23390 solution produced regionspecific effects. More importantly, it was previously demonstrated

Table 1. Step-through latencies on training day

\begin{tabular}{|c|c|c|c|c|c|}
\hline Experiment & $\begin{array}{c}\text { Nac } \\
\text { Subregion }\end{array}$ & Treatment & Groups & $N$ & Latency \\
\hline \multirow[t]{4}{*}{ Experiment 1} & Core & SCH 23390 & Vehicle & 9 & $5.1 \pm 1.1$ \\
\hline & & & 12.5 & 10 & $4.6 \pm 0.7$ \\
\hline & & & 25 & 11 & $4.4 \pm 0.5$ \\
\hline & & & 50 & 8 & $3 \pm 0.5$ \\
\hline \multirow[t]{4}{*}{ Experiment 2} & Shell & SCH 23390 & Vehicle & 8 & $4.9 \pm 0.7$ \\
\hline & & & 12.5 & 9 & $5.8 \pm 0.8$ \\
\hline & & & 25 & 8 & $4.2 \pm 0.5$ \\
\hline & & & 50 & 8 & $3.8 \pm 0.7$ \\
\hline \multirow[t]{2}{*}{ Experiment 3} & Core & SCH 23390 & Vehicle & 6 & $6.5 \pm 2.3$ \\
\hline & & & 50 & 8 & $5.5 \pm 1.1$ \\
\hline \multirow{3}{*}{ Experiment 4} & Core & Sulpiride & Vehicle & 12 & $4.7 \pm 0.6$ \\
\hline & & & 12.5 & 11 & $5.9 \pm 1$ \\
\hline & & & 25 & 15 & $5.5 \pm 0.9$ \\
\hline \multirow{3}{*}{ Experiment 5} & Shell & Sulpiride & Vehicle & 10 & $6.7 \pm 1.2$ \\
\hline & & & 12.5 & 9 & $5.2 \pm 1$ \\
\hline & & & 25 & 9 & $4.7 \pm 0.9$ \\
\hline \multirow[t]{2}{*}{ Experiment 6} & Core & Sulpiride & Vehicle & 9 & $4.4 \pm 0.7$ \\
\hline & & & 25 & 10 & $4.9 \pm 0$ \\
\hline \multirow[t]{2}{*}{ Experiment 7} & Shell & Sulpiride & Vehicle & 8 & $2.9 \pm 0.5$ \\
\hline & & & & 8 & $3.4 \pm 0.6$ \\
\hline
\end{tabular}

Latency in seconds ( \pm SEM) to step-through on the training day for the different groups in all experiments. There were no pre-existing differences between groups. 

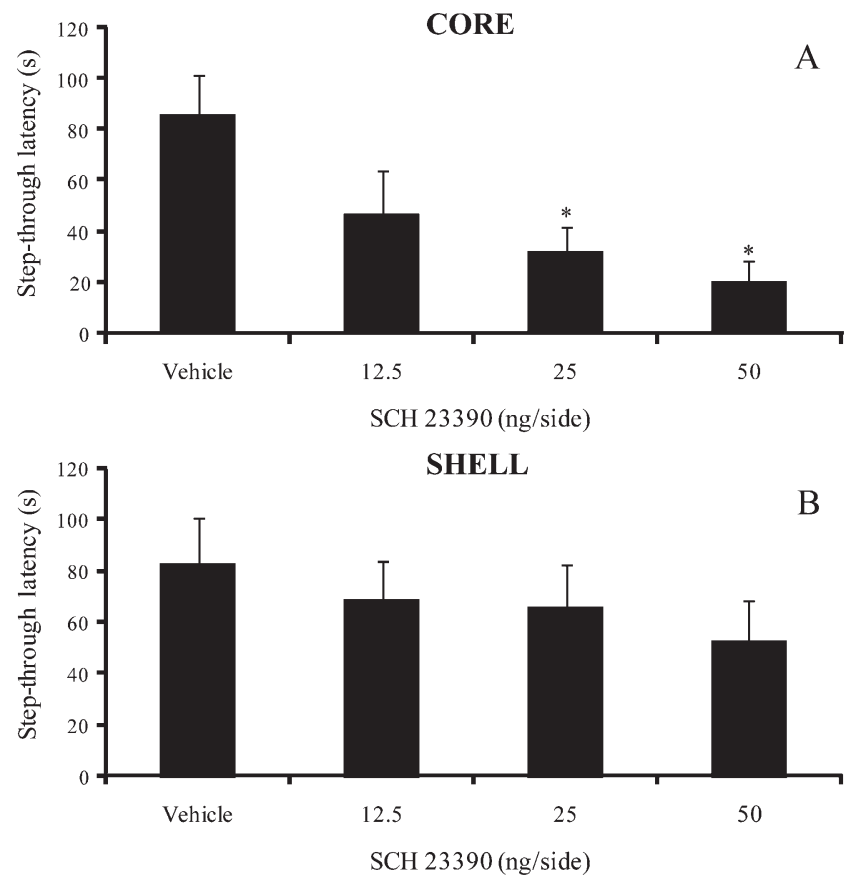

Figure 3. Effects of immediate post-training injections of vehicle or different doses of SCH 23390 within the Nac core $(A)$ or shell $(B)$ on stepthrough latency 24 h later. (*) $P<0.05$ SCH 23390 vs. vehicle.

that the concentration of sulpiride that is needed to reach a full pharmacological effect at a distance of $1 \mathrm{~mm}$ from the injection site is in the range of 1 to $10 \mathrm{mM}$, which is very high when compared with the pharmacological efficacy of these compounds, and the doses used in this study (Westerink and De Vries 2004). It is interesting to note that despite the higher density of D2 receptors in the shell than in the core, sulpiride was more effective in the former. This suggests that passive avoidance memory is more sensitive to $\mathrm{D} 2$ receptors activation in the core than in the shell.

These last results are in agreement with previous findings showing that dopamine injections within the core or the shell improve memory consolidation in the passive avoidance task, and that D2 receptors blockade in the two subregions impairs memory consolidation in the Morris water maze (MWM) task (Setlow and McGaugh 1998; LaLumiere et al. 2005). Nevertheless, this effect seems to be task dependent, since D1, but not D2 receptors blockade within the core has been reported to impair appetitive Pavlovian memory consolidation (Dalley et al. 2005).

To our knowledge this is the first experimental evidence to date demonstrating that activation of both DA receptors subtypes within the core are a necessary condition to consolidate complex forms of association. The simplest explanation for these different results is that aversive, but not appetitive memory requires D2 activation within the core (Dalley et al. 2005). However, it might also be that $\mathrm{D} 2$ receptors activation within the core are necessary to acquire the spatial-contextual component needed to solve the MWM and the passive avoidance task, but not to solve the cueguided Pavlovian learning. This interpretation implies that D1 and D2 receptors within the core accomplish different operations on memory consolidation, and that D2 receptors gates spatialcontextual information carried by hippocampal input to the Nac during memory consolidation. Electrophysiological evidence partially supports this view. Indeed, earlier electrophysiological and behavioral evidence demonstrated that D2, but not D1 receptors within the Nac regulate locomotor response induced by hippocampal manipulation and the effects of DA on the excitability of axon terminals of hippocampal-accumbens neurons (Yang and Mogenson 1986, 1987). However, more recent experimental evidence suggests the opposite, since brief activation of D1, but not D2 receptors has been demonstrated to induce long-lasting increases in the responsivity of nucleus-accumbens neurons to stimulation of excitatory projections from the hippocampus or basolateral amygdala (Taepavarapruk et al. 2000; Floresco et al. 2001a,b; Goto and Grace 2005). The discrepancy between these results and the difficulty to correlate them with behavioral processes is probably due to the many factors that can influence the physiological effects of mesoaccumbens DA on Nac neurons, such as the degree and timing of previous glutamatergic activation of Nac neurons, the spatial compartment (core and shell) where it occurs, previous activation or inhibition of nucleus accumbens efferent pathways, and the different stages of information processing (attention, learning, short-, or long-term memory) affected (Taepavarapruk et al. 2000; Floresco et al. 2001a,b; Goto and Grace 2005).

All together, the results of focal administration studies suggest that D1 receptors within the Nac core might be activated to integrate all forms of memory processed. On the contrary, D2 receptor activation might gait the control of hippocampal inputs on the neuronal activation induced by amygdala inputs to the Nac core immediately after learning, during memory consolidation. This might explain the ubiquitous role of D1 receptors within the core regardless of the behavioral task used, and the specific contribution of $\mathrm{D} 2$ receptors in hippocampal-dependent memory tasks (Setlow and McGaugh 1998; Smith-Roe and Kelley 2000; Dalley et al. 2005; Hernandez et al. 2005).

A strictly related issue is whether D2 receptors activation within the core and shell subregions have different roles in the consolidation of the information acquired in the one-trial inhibitory avoidance task. We suggested that D2 receptors blockade in the core might affect long-term context-reward memory formation by favoring the integration of contextual information coming from the hippocampus to emotional information coming from the basolateral amygdala, which are all necessary to perform the task. The injection sites in our study, indeed, targeted the medial core, where inputs from the basolateral amygdala, the hippocampus, and the prefrontal cortex converge (Mulder et al. 1998). On the contrary, the shell was generally targeted more ventrally, where the influence of the basolateral amygdala, the hypothalamus, and the infralimbic cortex, thus of internal statusrelated information, might predominate (as compared with context related once). Recent evidence demonstrated that the DA within the shell mediates not only memory consolidation but also memory improvement in the passive avoidance task induced by

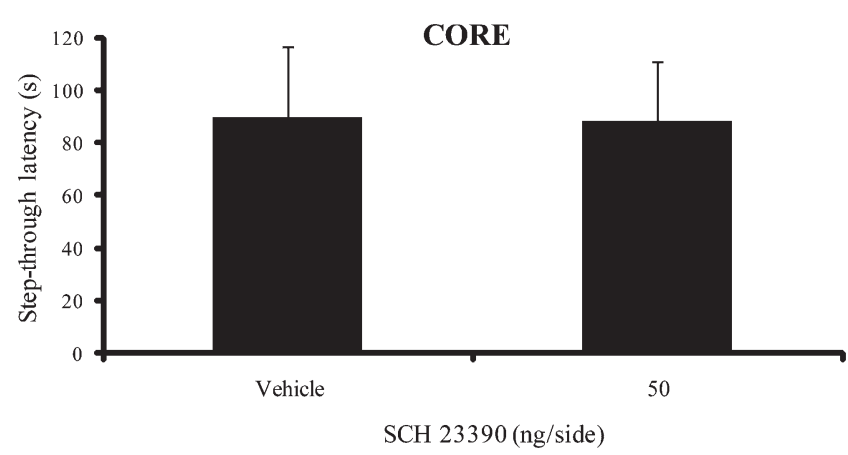

Figure 4. Effects of 120-min post-training injections of vehicle or $50 \mathrm{ng} /$ side of SCH 23390 within the Nac core on step-through latency $24 \mathrm{~h}$ later. 

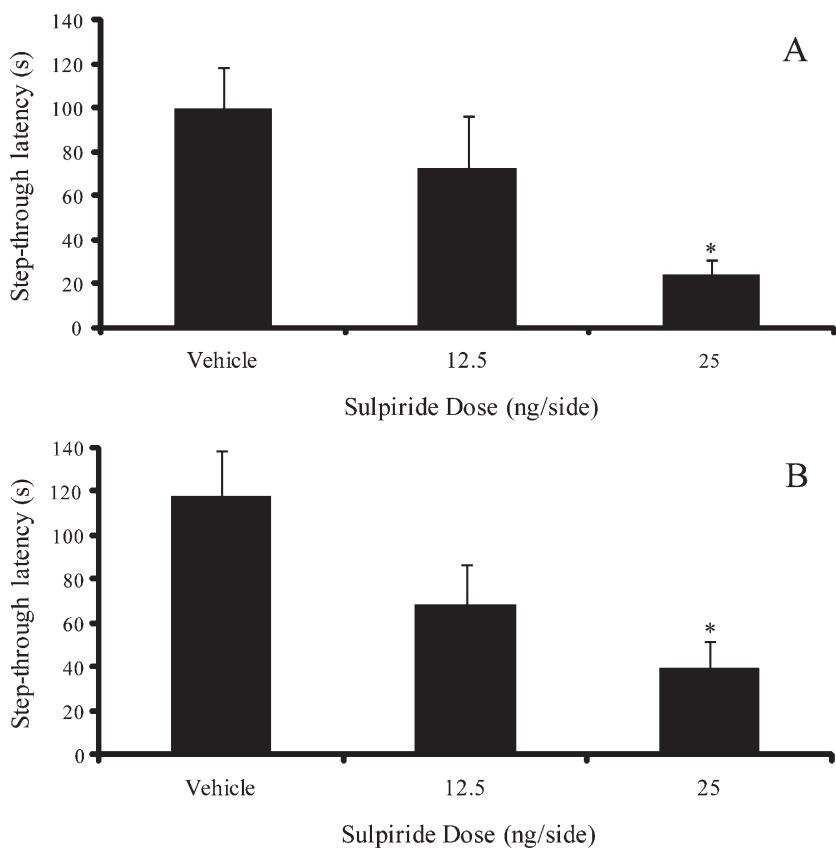

Figure 5. Effects of immediate post-training injections of vehicle or different doses of sulpiride within the Nac core $(A)$ or shell $(B)$ on stepthrough latency $24 \mathrm{~h}$ later. $\left(^{*}\right) P<0.05$ sulpiride vs. vehicle.

dopamine stimulation within the basolateral amygdala (LaLumiere et al. 2005). We speculate that DA within the shell might affect memory formation and memory strength by modulating the motivational impact of the stimuli, and that this effect is mediated by $\mathrm{D} 2$ receptors activation.

In conclusion, we confirm a general role of dopamine and both DA receptors subtypes within the Nac in conditional memory consolidation (Lorenzini et al. 1995; Setlow and McGaugh 1999). It is interesting to note that systemic administration studies of DAergic drugs consistently confirm the role of both receptors subtypes in aversive memory consolidation. In fact, systemic administration of D1 and D2 antagonists in CD1 outbred mice (Castellano et al. 1991) has been proven to block memory consolidation in the one-trial passive avoidance task. However, systemic blockade of DA receptors subtypes impaired and improved aversive memory consolidation in C57BL/6J and DBA/2J inbred mice, respectively, while opposite effects were observed with DAergic agonists (Cestari et al. 1992). Although no focal administration studies have been performed yet, these two inbred mouse strains are known to differ in their reactivity of the Nac dopaminergic system to systemic administration of DAergic drugs (Zocchi et al.1998; Ventura et al. 2004), therefore suggesting, once again, the Nac as a possible neural substrate for this genotypedependent memory effect of DA.

These data have their own broad relevance, since they prove that DA in the Nac is necessary not only to guide attention and ongoing behavior, but also for the short- or long-term storage of conditional associations or spatial information (Ploeger et al. 1994; Setlow and McGaugh 1998; Di Ciano et al. 2001; Mele et al. 2004; Dalley et al. 2005; Ferretti et al. 2005; LaLumiere et al. 2005). In other words, it is also involved in off-line cognitive processing. In addition, we demonstrated that dopamine receptors subtypes, D1 and D2, can modulate this process differently depending on the Nac subregion, the core and shell. These results, in our opinion, also have a great clinical relevance, since they parallel experimental evidence in humans demonstrating that during symptoms, provo- cation activation in the region of the left amygdala/nucleus accumbens occurs only in PTSD-affected patients, but not in combat control or normal control subjects (Liberzon et al. 1999). Since antipsychotic drugs are already in use for a variety of psychiatric disorders in humans, the results of this study supports their potential use for early intervention after a traumatic experience in humans in order to prevent the development of posttraumatic stress disorder. Therefore, the demonstration that the D2 antagonist consistently blocks memory consolidation for aversive events might also have therapeutic implications.

\section{Materials and Methods}

\section{Animals}

The subjects were adult CD1 male outbred mice obtained from Charles River. Upon arrival, mice were housed in groups of 12 in standard breeding cages $(46 \times 26 \times 21.8 \mathrm{~cm})$, placed in a rearing room at a constant temperature $\left(22 \pm 1^{\circ} \mathrm{C}\right)$, and maintained on a $12 \mathrm{~h}$ light/dark cycle with food and water available ad libitum. At the time of surgery they were 9-12 wk old. Every possible effort was made to minimize animal suffering, and all procedures were in strict accordance with the European Communities Council directives (86/609/EEC) and regulations on the use of animals in research and NIH guidelines on animal care.

\section{Surgery}

Mice were anesthetized by intraperitoneal injection of chloral hydrate $(500 \mathrm{mg} / \mathrm{kg}$; Fluka) and placed in a stereotaxic apparatus (David Kopf Instruments) with mouse adapter and lateral ear bars. The mice were bilaterally implanted with 7-mm-long stainlesssteel cannulae $2 \mathrm{~mm}$ dorsal to the nucleus accumbens core or the nucleus accumbens shell. The stereotaxic coordinates used were $\mathrm{AP},+1.5 \mathrm{~mm} ; \mathrm{L}, \pm 1 \mathrm{~mm}, \mathrm{DV},-2.1 \mathrm{~mm}$, and $\mathrm{AP},+1.5 \mathrm{~mm}, \mathrm{~L}, \pm 0.5$ $\mathrm{mm}, \mathrm{DV},-2.6 \mathrm{~mm}$ relative to bregma, respectively, for the core and the shell, according to the atlas of Franklin and Paxinos
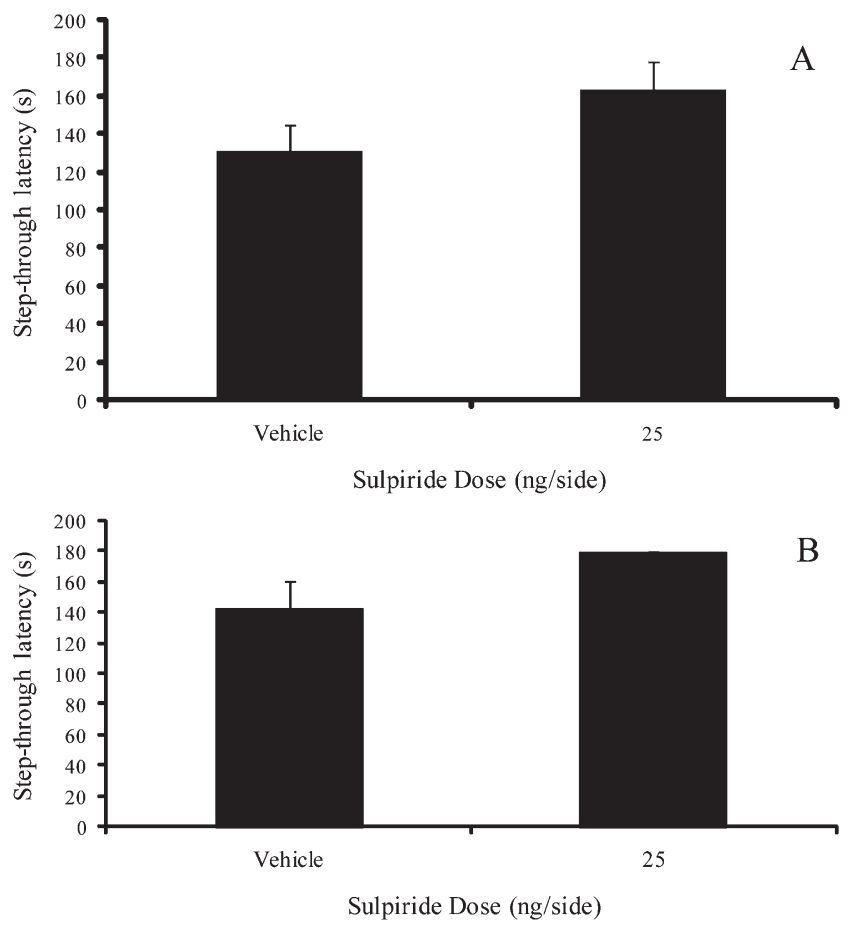

Figure 6. Effects of 120-min post-training injections of vehicle or 25 $\mathrm{ng} /$ side of sulpiride within the Nac core $(A)$ or shell $(B)$ on step-through latency $24 \mathrm{~h}$ later. 
(1997). Guide cannulae were secured in place with dental cement. Mice were then allowed to recover for 5-7 $d$ in groups of four in standard breeding cages $(25 \times 20 \times 14 \mathrm{~cm})$.

\section{Behavioral task}

The step-through inhibitory avoidance apparatus consisted of a straight alley divided into two compartments, one $12.5 \mathrm{~cm}$ long and the other $25 \mathrm{~cm}$ long. The small compartment was made of white Plexiglas and illuminated by a tensor lamp $(60 \mathrm{~W})$. The floor of the longer compartment consisted of two oblique stainless-steel plates connected to an electric source, and it was equipped with a removable cover made of black Plexiglas to allow darkness in the compartment. The two compartments were separated by a black sliding door.

\section{Behavioral procedures}

On the training day, each mouse was placed in the light compartment, facing away from the dark compartment, and the door leading to the dark compartment was raised. When the mouse had stepped with all four paws into the dark compartment, the door was closed and an electric foot shock $(0.5 \mathrm{~mA}, 50 \mathrm{~Hz}, 2 \mathrm{sec})$ was delivered. Memory retention was always tested $24 \mathrm{~h}$ later following a similar procedure, except that no shock was delivered. Cutoff was set at $180 \mathrm{sec}$.

\section{Drugs and injection procedure}

The doses of dopamine antagonists were chosen based on preliminary experiments and previous studies (Mele et al. 2004; Ferretti et al. 2005). The D1 receptor antagonist, SCH 23390 $(\mathrm{SCH} ; \mathrm{RBI})$, was dissolved in saline solution $(0.9 \% \mathrm{NaCl}$ in distilled water). Sulpiride (SULP; Sigma-Aldrich) was used as the D2 antagonist; it was dissolved in a drop of acetic acid and then diluted with saline solution to the final concentration, and the $\mathrm{pH}$ was adjusted to 7.0 with $\mathrm{NaOH}$. All solutions were administered in a volume of $0.2 \mu \mathrm{L} /$ side. Drug-injected animals were always compared with mice injected with the same volume of the same vehicle solution used to dilute the different drugs. An injection needle was inserted into the guide cannula, which was connected by plastic tubing to a $2-\mu \mathrm{L}$ Hamilton syringe; the process took 2 min, with one additional minute to allow diffusion. In Experiments $1,2,4$, and 5 drug injection was performed immediately after training, while in the remaining experiments drugs were injected $120 \mathrm{~min}$ after training.

\section{Experiments}

In the first two experiments injections of the D1 receptor antagonist, SCH 23390, within the Nac core (Experiment 1) and the shell (Experiment 2) subregions were performed immediately post-training. Four different experimental groups, one for each experiment, were injected with vehicle, $12.5,25$, or $50 \mathrm{ng} / \mathrm{side}$ of SCH 23390. A further experiment (Experiment 3) tested the effects of 120-min post-training injections of D1 receptor antagonist, SCH 23390, within the Nac core, by using two different experimental groups injected with vehicle or $50 \mathrm{ng} / \mathrm{side}$ of SCH 23390. In Experiments 4 and 5, immediate post-training injections of D2 receptor antagonist, sulpiride, were administered within the Nac core and the shell, respectively. Three different experimental groups were used, one for each experiment, injected with vehicle, 12.5 or $25 \mathrm{ng} /$ side of sulpiride. In the last two experiments, D2 antagonist, sulpiride, was administered 120 min post-training in the core (Experiment 6) and in the shell (Experiment 7). Two different experimental groups, one for each experiment, were injected with vehicle or $25 \mathrm{ng} /$ side of sulpiride.

\section{Histological analysis}

At the completion of the experiments, mice were sacrificed with an overdose of chloral hydrate, and the brains were removed and fixed in a $4 \%$ formaldehyde solution. Cannula placements were determined by examining serial $60-\mu \mathrm{m}$ coronal sections stained with cresyl violet.

\section{Data collection and statistics}

Step-through latency was operatively defined as the time(s) from when the animals turned their heads toward the sliding door and stepped all four paws into the dark compartment. The effects of drug treatments on training and testing latency on passive avoidance were analyzed by using one-way ANOVA, with dopamine antagonist doses as factor between groups, separately for the core and shell of the nucleus accumbens. Fisher post-hoc analysis was used when appropriate.

\section{Acknowledgments}

The present study was supported by P.R.I.N. and F.I.R.B. grants from M.I.U.R. (to A.O. to A.M.) and grants DCMC and SaC from A.S.I. (to A.O. and A.M.).

\section{References}

Bossert, J.M., Poles, G.C., Wihbey, K.A., Koya, E., and Shaham, Y. 2007. Differential effects of blockade of dopamine D1-family receptors in nucleus accumbens core or shell on reinstatement of heroin seeking induced by contextual and discrete cues. J. Neurosci. 27: 12655-12663.

Castellano, C., Cestari, V., Cabib, S., and Puglisi-Allegra, S. 1991. Posttraining dopamine receptor agonists and antagonists affect memory storage in mice irrespective of their selectivity for D1 or D2 receptors. Behav. Neural Biol. 56: 283-291.

Cepeda, C. and Levine, M.S. 1998. Dopamine and N-methyl-D-aspartate receptor interactions in the neostriatum. Dev. Neurosci. 20: 1-18.

Cestari, V., Castellano, C., Cabib, S., and Puglisi-Allegra, S. 1992. Straindependent effects of post-training dopamine receptor agonists and antagonists on memory storage in mice. Behav. Neural Biol. 58: 58-63.

Cheer, J.F., Wassum, K.M., Sombers, L.A., Heien, M.L., Ariansen, J.L., Aragona, B.J., Phillips, P.E., and Wightman, R.M. 2007. Phasic dopamine release evoked by abused substances requires cannabinoid receptor activation. J. Neurosci. 27: 791-795.

Cheng, J. and Feenstra, M.G. 2006. Individual differences in dopamine efflux in nucleus accumbens shell and core during instrumental learning. Learn. Mem. 13: 168-177.

Cools, A.R., Miwa, Y., and Koshikawa, N. 1995. Role of dopamine D1 and D2 receptors in the nucleus accumbens in jaw movements of rats: A critical role of the shell. Eur. J. Pharmacol. 286: 41-47.

da Cunha, I.C., Lopes, A.P., Steffens, S.M., Ferraz, A., Vargas, J.C., de Lima, T.C., Marino Neto, J., Paschoalini, M.A., and Faria, M.S. 2008. The microinjection of AMPA receptor antagonist into the accumbens shell, but not into the accumbens core, induces anxiolysis in an animal model of anxiety. Behav. Brain Res. 188: 91-99.

Dalley, J.W., Lääne, K., Theobald, D.E., Armstrong, H.C., Corlett, P.R., Chudasama, Y., and Robbins, T.W. 2005. Time-limited modulation of appetitive Pavlovian memory by D1 and NMDA receptors in the nucleus accumbens. Proc. Natl. Acad. Sci. 102: 6189-6194.

De Leonibus, E., Verheij, M.M., Mele, A., and Cools, A. 2006. Distinct kinds of novelty processing differentially increase extracellular dopamine in different brain regions. Eur. J. Neurosci. 23: 1332-1340.

Di Chiara, G. and Bassareo, V. 2007. Reward system and addiction: What dopamine does and doesn't do. Curr. Opin. Pharmacol. 7: 69-76.

Di Chiara, G., Bassareo, V., Fenu, S., De Luca, M.A., Spina, L., Cadoni, C., Acquas, E., Carboni, E., Valentini, V., and Lecca, D. 2004. Dopamine and drug addiction: The nucleus accumbens shell connection. Neuropharmacology (Suppl. 1) 47: 227-241.

Di Ciano, P. and Everitt, B.J. 2004. Direct interactions between the basolateral amygdala and nucleus accumbens core underlie cocaineseeking behavior by rats. J. Neurosci. 24: 7167-7173.

Di Ciano, P., Cardinal, R.N., Cowell, R.A., Little, S.J., and Everitt, B.J. 2001. Differential involvement of NMDA, AMPA/kainate, and dopamine receptors in the nucleus accumbens core in the acquisition and performance of pavlovian approach behavior. J. Neurosci. 21: 9471-9477.

Ferretti, V., Florian, C., Costantini, V.J., Roullet, P., Rinaldi, A., De Leonibus, E., Oliverio, A., and Mele, A. 2005. Co-activation of glutamate and dopamine receptors within the nucleus accumbens is required for spatial memory consolidation in mice. Psychopharmacology 179: 108-116.

Floresco, S.B., Blaha, C.D., Yang, C.R., and Phillips, A.G. 2001a. Dopamine D1 and NMDA receptors mediate potentiation of basolateral amygdalaevoked firing of nucleus accumbens neurons. J. Neurosci. 21: 6370-6376.

Floresco, S.B., Blaha, C.D., Yang, C.R., and Phillips, A.G. 2001b. Modulation of hippocampal and amygdalar-evoked activity of nucleus accumbens 
neurons by dopamine: Cellular mechanisms of input selection. $J$. Neurosci. 21: 2851-2860.

Franklin, K.B.J. and Paxinos, G. 1997. The mouse brain in stereotaxic coordinates, 3rd ed. Academic Press, San Diego, CA.

Goto, Y. and Grace, A.A. 2005. Dopaminergic modulation of limbic and cortical drive of nucleus accumbens in goal-directed behavior. Nat. Neurosci. 8: 805-812.

Hernandez, P.J., Andrzejewski, M.E., Sadeghian, K., Panksepp, J.B., and Kelley, A.E. 2005. AMPA/kainate, NMDA, and dopamine D1 receptor function in the nucleus accumbens core: A context-limited role in the encoding and consolidation of instrumental memory. Learn. Mem. 12: 285-295.

Jongen-Rêlo, A.L., Kaufmann, S., and Feldon, J. 2003. A differential involvement of the shell and core subterritories of the nucleus accumbens of rats in memory processes. Behav. Neurosci. 117: $150-168$.

Koshikawa, N., Kitamura, M., Kobayashi, M., and Cools, A.R. 1996a. Contralateral turning elicited by unilateral stimulation of dopamine D2 and D1 receptors in the nucleus accumbens of rats is due to stimulation of these receptors in the shell, but not the core, of this nucleus. Psychopharmacology 126: 185-190.

Koshikawa, N., Kitamura, M., Kobayashi, M., and Cools, A.R. 1996b. Behavioural effects of 7-OH-DPAT are solely due to stimulation of dopamine D2 receptors in the shell of the nucleus accumbens; turning behaviour. Eur. J. Pharmacol. 308: 235-241.

Kuo, Y.M., Liang, K.C., Chen, H.H., Cherng, C.G., Lee, H.T., Lin, Y., Huang, A.M., Liao, R.M., and Yu, L. 2007. Cocaine-but not methamphetamineassociated memory requires de novo protein synthesis. Neurobiol. Learn. Mem. 87: 93-100.

LaLumiere, R.T., Nawar, E.M., and McGaugh, J.L. 2005. Modulation of memory consolidation by the basolateral amygdala or nucleus accumbens shell requires concurrent dopamine receptor activation in both brain regions. Learn. Mem. 12: 296-301.

Liberzon, I., Taylor, S.F., Amdur, R., Jung, T.D., Chamberlain, K.R., Minoshima, S., Koeppe, R.A., and Fig, L.M. 1999. Brain activation in PTSD in response to trauma-related stimuli. Biol. Psychiatry 45: $817-826$.

Liberzon, I., Taylor, S.F., Phan, K.L., Britton, J.C., Fig, L.M., Bueller, J.A., Koeppe, R.A., and Zubieta, J.K. 2007. Altered central micro-opioid receptor binding after psychological trauma. Biol. Psychiatry 61: $1030-1038$

Lorenzini, C.A., Baldi, E., Bucherelli, C., and Tassoni, G. 1995. Timedependent deficits of rat's memory consolidation induced by tetrodotoxin injections into the caudate-putamen, nucleus accumbens, and globus pallidus. Neurobiol. Learn. Mem. 63: 87-93.

Lu, X.Y., Ghasemzadeh, M.B., and Kalivas, P.W. 1998. Expression of D1 receptor, D2 receptor, substance P and enkephalin messenger RNAs in the neurons projecting from the nucleus accumbens. Neuroscience $\mathbf{8 2}$ : 767-780.

Mele, A., Avena, M., Roullet, P., De Leonibus, E., Mandillo, S., Sargolini, F, Coccurello, R., and Oliverio, A. 2004. Nucleus accumbens dopamine receptors in the consolidation of spatial memory. Behav. Pharmacol. 15: 423-431.

Missale, C., Nash, S.R., Robinson, S.W., Jaber, M., and Caron, M.G. 1998. Dopamine receptors: From structure to function. Physiol. Rev. 78: $189-225$.

Mulder, A.B., Hodenpijl, M.G., and Lopes da Silva, F.H. 1998. Electrophysiology of the hippocampal and amygdaloid projections to the nucleus accumbens of the rat: Convergence, segregation, and interaction of inputs. J. Neurosci. 18: 5095-5102.
Navakkode, S., Sajikumar, S., and Frey, J.U. 2007. Synergistic requirements for the induction of dopaminergic D1/D5-receptor-mediated LTP in hippocampal slices of rat CA1 in vitro. Neuropharmacology 52: $1547-1554$

Pavic, L., Gregurek, R., Petrovic, R., Petrovic, D., Varda, R., Vukusic, H., and Crnkovic-Markovic, S. 2003. Alterations in brain activation in posttraumatic stress disorder patients with severe hyperarousal symptoms and impulsive aggressiveness. Eur. Arch. Psychiatry Clin. ANeurosci. 253: 80-83.

Ploeger, G.E., Spruijt, B.M., and Cools, A.R. 1994. Spatial localization in the Morris water maze in rats: Acquisition is affected by intra-accumbens injections of the dopaminergic antagonist haloperidol. Behav. Neurosci. 108: 927-934.

Schmidt, H.D., Anderson, S.M., and Pierce, R.C. 2006. Stimulation of D1like or D2 dopamine receptors in the shell, but not the core, of the nucleus accumbens reinstates cocaine-seeking behaviour in the rat. Eur. J. Neurosci. 23: 219-228.

Setlow, B. and McGaugh, J.L. 1998. Sulpiride infused into the nucleus accumbens posttraining impairs memory of spatial water maze training. Behav. Neurosci. 112: 603-610.

Setlow, B. and McGaugh, J.L. 1999. Differential effects of immediate posttraining sulpiride infusions into the nucleus accumbens core and shell on retention in the Morris water maze. Psychobiology 27: 248-255.

Smith-Roe, S.L. and Kelley, A.E. 2000. Coincident activation of NMDA and dopamine D1 receptors within the nucleus accumbens core is required for appetitive instrumental learning. J. Neurosci. 20: 7737-7742.

Surmeier, D.J., Ding, J., Day, M., Wang, Z., and Shen, W. 2007. D1 and D2 dopamine-receptor modulation of striatal glutamatergic signaling in striatal medium spiny neurons. Trends Neurosci. 30: 228-235.

Taepavarapruk, P., Floresco, S.B., and Phillips, A.G. 2000. Hyperlocomotion and increased dopamine efflux in the rat nucleus accumbens evoked by electrical stimulation of the ventral subiculum: Role of ionotropic glutamate and dopamine D1 receptors. Psychopharmacology 151: 242-251.

Ventura, R., Alcaro, A., Cabib, S., Conversi, D., Mandolesi, L., and PuglisiAllegra, S. 2004. Dopamine in the medial prefrontal cortex controls genotype-dependent effects of amphetamine on mesoaccumbens dopamine release and locomotion. Neuropsychopharmacology 29: 72-80.

Westerink, B.H. and De Vries, J.B. 2004. A method to evaluate the diffusion rate of drugs from a microdialysis probe through brain tissue. J. Neurosci. Methods 109: 53-58.

Wolf, M.E., Mangiavacchi, S., and Sun, X. 2003. Mechanisms by which dopamine receptors may influence synaptic plasticity. Ann. N. Y. Acad. Sci. 1003: 241-249.

Yang, C.R. and Mogenson, G.J. 1986. Dopamine enhances terminal excitability of hippocampal-accumbens neurons via D2 receptor: Role of dopamine in presynaptic inhibition. J. Neurosci. 6: 2470-2478.

Yang, C.R. and Mogenson, G.J. 1987. Hippocampal signal transmission to the pedunculopontine nucleus and its regulation by dopamine D2 receptors in the nucleus accumbens: An electrophysiological and behavioural study. Neuroscience 23: 1041-1055.

Zahm, D.S. and Brog, J.S. 1992. On the significance of subterritories in the "accumbens" part of the rat ventral striatum. Neuroscience 50: 751-767.

Zocchi, A., Orsini, C., Cabib, S., and Puglisi-Allegra, S. 1998. Parallel strain-dependent effect of amphetamine on locomotor activity and dopamine release in the nucleus accumbens: An in vivo study in mice. Neuroscience 82: 521-528.

Received August 7, 2008; accepted in revised form October 23, 2008. 


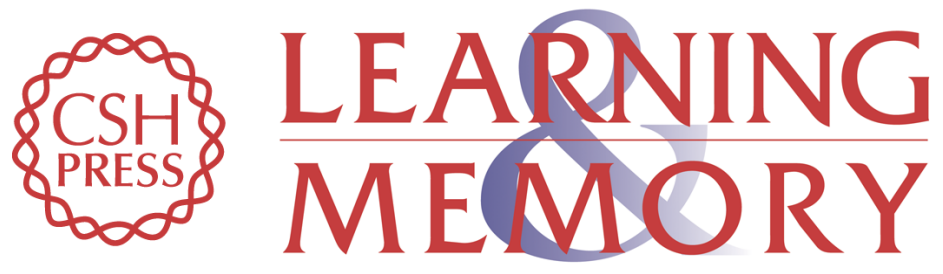

\section{Role of dopamine receptors subtypes, D1-like and D2-like, within the nucleus accumbens subregions, core and shell, on memory consolidation in the one-trial inhibitory avoidance task}

Francesca Managò, Claudio Castellano, Alberto Oliverio, et al.

Learn. Mem. 2009, 16:

Access the most recent version at doi:10.1101/Im.1177509

References This article cites 47 articles, 13 of which can be accessed free at:

http://learnmem.cshlp.org/content/16/1/46.full.html\#ref-list-1

License

Email Alerting

Receive free email alerts when new articles cite this article - sign up in the box at the Service top right corner of the article or click here. 